\title{
Evidence of an $X X / X Y$ sex chromosome system in the fish Dormitator maculatus (Teleostei, Eleotrididae)
}

\author{
Claudio Oliveira ${ }^{1}$ and Lurdes Foresti de Almeida Toledo ${ }^{2}$ \\ ${ }^{1}$ Departamento de Morfologia, Instituto de Biociências, UNESP - Universidade Estadual Paulista, \\ Botucatu, SP, Brazil. \\ ${ }^{2}$ Departamento de Genética e Biologia Evolutiva, Instituto de Biociências, Universidade de São Paulo, \\ São Paulo, SP, Brazil.
}

\begin{abstract}
The fish Dormitator maculatus has a chromosomes number of $2 n=46$, females having a karyotype of $14 \mathrm{M}, 28 \mathrm{SM}, 2$ ST and 2A and males $13 \mathrm{M}, 28 \mathrm{SM}, 3$ ST and 2A. The presence of a heteromorphic pair in the males and a corresponding homomorphic pair in the females suggest the occurrence of an $X X / X Y$ sex chromosome system in $D$. maculatus. The putative $\mathrm{X}$ chromosome has a pericentromeric $\mathrm{C}$-band positive segment and the putative $\mathrm{Y}$ chromosome a C-band positive short arm.
\end{abstract}

Key words: fish cytogenetics, karyotypes, Ag-NORs, C-band, sex chromosomes.

Received: June 22, 2005; Accepted: March 15, 2006.

Although only about $10 \%$ of karyotyped fish display differentiated sex chromosomes, seven systems involving male heterogamety $\left(\mathrm{XY}, \mathrm{X} 0\right.$ and $\left.\mathrm{X}_{1} \mathrm{X}_{2} \mathrm{Y}\right)$, female heterogamety $\left(\mathrm{ZW}, \mathrm{Z} 0\right.$ and $\left.\mathrm{ZW}_{1} \mathrm{~W}_{2}\right)$ and an unusual $\mathrm{WXZ}$ system in the platyfish have been described (Devlin and Nagahama, 2002). The ZZ/ZW system is the most common sex chromosome system and the $\mathrm{XX} / \mathrm{X} 0$ (ten species) and $\mathrm{ZZ/Z0} \mathrm{(three} \mathrm{species)} \mathrm{systems,} \mathrm{are} \mathrm{the} \mathrm{most} \mathrm{rare} \mathrm{(Devlin}$ and Nagahama, 2002). Cytogenetic differences detected between sex chromosomes include: additions or deletions of C-band positive segments (Phillips and Ihssen, 1985; Andreata et al., 1992, 1993; Cano et al., 1996; Stein et al., 2001), reductions in chromosome size (Park and Kang, 1979), increases in chromosome size (Galetti et al., 1981) and chromosome rearrangements (Uyeno and Miller, 1971; Thorgaard, 1978; Bertollo et al., 1983; Almeida Toledo et al., 1984; Pezold, 1984; Vitturi et al., 1991).

The family Eleotrididae is comprised of about 35 genera and 150 species inhabiting tropical and subtropical areas worldwide (Nelson, 1994). Fish of this family are mainly marine but some species live in brackish and freshwater (Nelson, 1994). The subfamily Eleotridinae is represented in the Neotropical region by six genera, including the genus Dormitator (Kullander, 2003). The present paper

Send correspondence to C. Oliveira. Departamento de Morfologia, Instituto de Biociências, UNESP - Universidade Estadual Paulista, 18618-000 Botucatu, SP, Brazil. E-mail: claudio@ ibb.unesp.br. describes the karyotypes, nucleolus organizer regions (NORs) and distribution of C-band positive segments of Dormitator maculatus and reports the occurrence of a putative case of an $\mathrm{XX} / \mathrm{XY}$ sex chromosome system in this species.

Seven males and five females Dormitator maculatus from the Itinga River, Mongaguá, São Paulo state, Brazil were karyotyped. Mitotic chromosome preparations were obtained from kidney and gill tissues using the air-drying technique of Bertollo et al. (1978). Chromosome morphology was determined on the basis of arm ratio, as proposed by Levan et al. (1964) and chromosomes were classified as metacentric (M), submetacentric (SM), subtelocentric (ST) or acrocentric (A). Silver staining of nucleolar organizer regions (Ag-NORs) followed the technique proposed by Howell and Black (1980) and C-banding was performed as described by Sumner (1972).

We found a $D$. maculatus chromosome number of $2 \mathrm{n}=46$, with females having a karyotype of $14 \mathrm{M}, 28 \mathrm{SM}, 2$ ST and 2A (Figure 1a) and males 13 M, 28 SM, 3 ST and 2A (Figure 1b). The silver staining of the chromosomes revealed that the Ag-NORs were terminally located on the short arms of a larger SM pair (pair 10) (Figure 1a). Several faintly stained C-band positive segments were visible on many autosomes, mainly at the centromeric or pericentromeric position and distributed over the short arms of some chromosomes (Figure 2). The putative $\mathrm{X}$ chromosome had a pericentromeric C-band positive segment (Figure 2a) and 

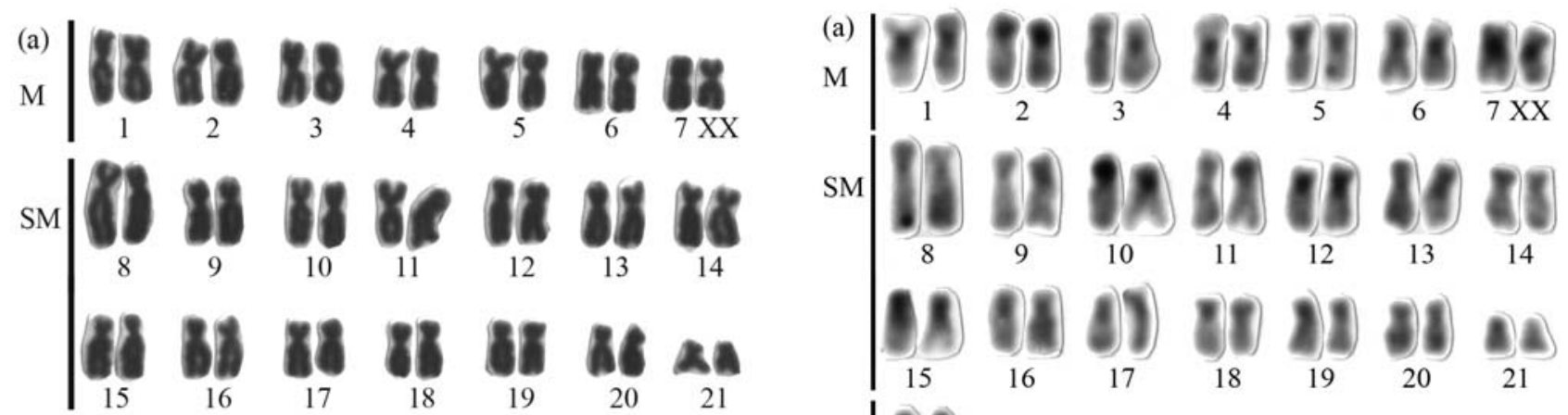

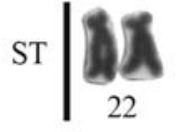

\begin{tabular}{l|l}
$\mathrm{A}$ & $\mathbf{0}$ \\
23
\end{tabular}

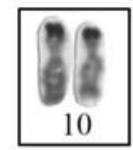

(b)

M
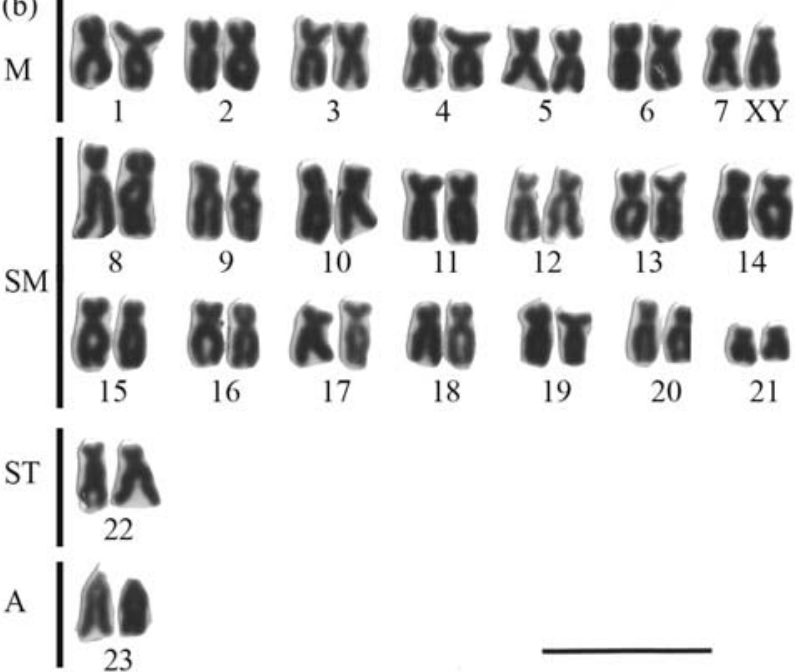

Figure 1 - Giemsa stained karyotypes of Dormitator maculatus. (a) Female; (b) Male. The Ag-NOR-bearing chromosome pair is shone in the in-

the putative Y chromosome a heterochromatic short arm (Figure 2b).

Cytogenetic studies conducted in eleven species of Eleotrididae show that the diploid number ranges from $2 n=44$ to 48 among ten species investigated (Klinkhardt $e t$ al., 1995). However, Nogusa (1955) reported the occurrence of $2 n=62$ chromosomes in the Eleotrididae species Mogrunda obscura. An interesting characteristic of the members of Eleotrididae is the common occurrence of many uniarmed chromosomes, thus differing from the karyotype of Dormitator maculatus that has mainly biarmed chromosomes. A recent cytogenetic investigation of specimens of Awaous strigatus (Eleotrididae) from Belém (Pará state, Brazil) suggested the occurrence of an $\mathrm{X}_{1} \mathrm{X}_{2} \mathrm{Y}$ sex chromosome system in this species (I.L. Souza, personal communication).

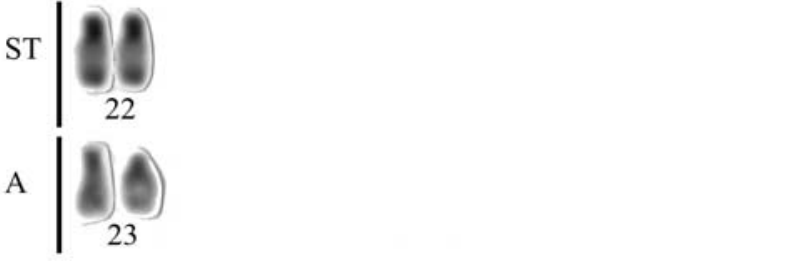

\begin{tabular}{l|} 
(b) \\
M
\end{tabular}
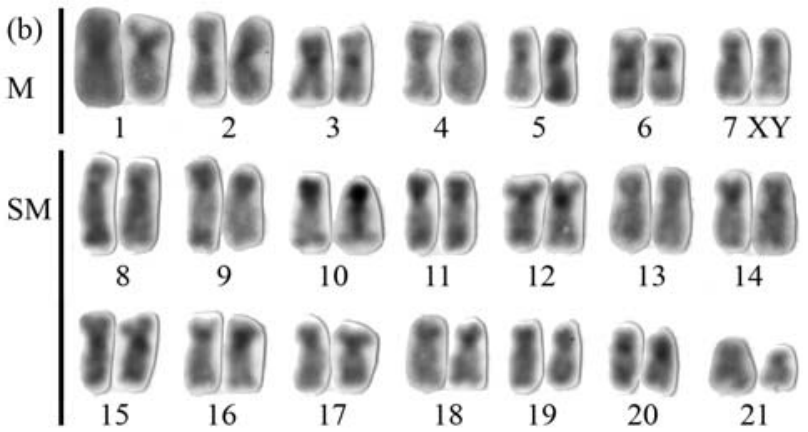

ST
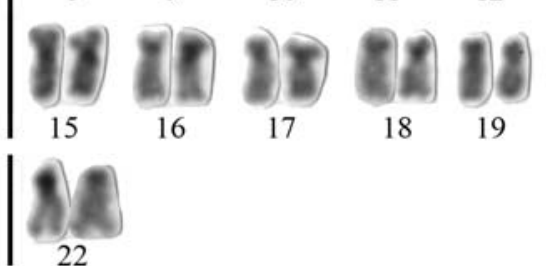

13

14

A

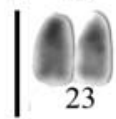

Figure 2 - C-banded karyotypes of Dormitator maculatus. (a) Female; (b) Male. $\mathrm{Bar}=10 \mu \mathrm{m}$

The presence of a heteromorphic pair in the males and a corresponding homomorphic pair in the female $D$. maculatus suggest the occurrence of an XX/XY sex chromosome system in this species. The morphological difference observed between the homologues chromosomes of the heteromorphic pair was probably due to the occurrence of a pericentric inversion, changing a primitive $\mathrm{M}$ chromosome from a homomorphic pair to an ST chromosome. Ohno (1974) considered the occurrence of a chromosome inversion to be the first step in the evolution of sex chromosomes, and recent studies have shown that this type of chromosome rearrangement is very important (if not the most important) rearrangement in species evolution (Livingstone and Riesenberg, 2003; Navarro and Barton 2003). Further studies including additional chromosome banding techniques will be very useful to confirm the presence of an $\mathrm{XX} / \mathrm{XY}$ sex chromosome system in Dormitator maculatus. 


\section{Acknowledgments}

The authors are grateful to Dr. J.L. Figueiredo for the taxonomic identification of the specimens. The Brazilian agencies FAPESP and CNPq provided funds to support this study.

\section{References}

Almeida Toledo LF, Foresti F and Toledo Filho SA (1984) Complex sex chromosome system in Eigenmannia sp. (Pisces, Gymnotiformes). Genetica 64:165-169.

Andreata AA, Almeida-Toledo LF, Oliveira C and Toledo Filho SA (1992) Chromosome studies in Hypoptopomatinae (Pisces, Siluriformes, Loricariidae): I. XX/XY sex chromosome heteromorphism in Pseudotocinclus tietensis. Cytologia 57:369-372.

Andreata AA, Almeida-Toledo LF, Oliveira C and Toledo Filho SA (1993) Chromosome studies in Hypoptopomatinae (Pisces, Siluriformes, Loricariidae): II. ZZ/ZW sex-chromosome system, B chromosomes, and constitutive heterochromatin differentiation in Microlepidogaster leucofrenatus. Cytogenet Cell Genet 63:215-220.

Bertollo LAC, Takahashi CS and Moreira-Filho O (1983) Multiple sex chromosomes in the genus Hoplias (Pisces, Erythrinidae). Cytologia 48:1-12.

Bertollo LAC, Takahashi CS and Moreira-Filho O (1978) Cytotaxonomic considerations on Hoplias lacerdae (Pisces, Erythrinidae). Brazil J Genet 1:103-120.

Cano J, Pretel A, Melendez S, Garcia F, Caputo V, Fenocchio AS and Bertollo LAC (1996) Determination of early stages of sex chromosome differentiation in the sea bass Dicentrarchus labrax L. (Pisces, Perciformes). Cytobios 87:45-59.

Devlin RH and Nagahama Y (2002) Sex determination and sex differentiation in fish: An overview of genetic, physiological, and environmental influences. Aquaculture 208:191364.

Galetti Jr. PM, Foresti F, Bertollo LAC and Moreira-Filho O (1981) Heteromorphic sex chromosomes in three species of the genus Leporinus (Pisces, Anostomidae). Cytogenet Cell Genet 29:138-142.

Howell WM and Black DA (1980) Controlled silver staining of nucleolus organizer regions with a protective colloidal developer: A 1-step method. Experientia 36:1014-1015.
Klinkhardt M, Tesche M and Greven H (1995) Database of Fish Chromosomes. Westarp-Wiss, Magdeburg, $237 \mathrm{pp}$.

Kullander SO (2003) Family Gobiidae (gobies). In: Reis RE, Kullander SO and Ferraris Jr. CJ (eds), Check List of the Freshwater Fishes of South America. Edipucrs, Porto Alegre, pp 657-665.

Levan A, Fredga K and Sandberg AA (1964) Nomenclature for centromeric position on chromosomes. Hereditas 52:201220.

Livingstone K and Riesenberg LH (2003) Chromosomal evolution and speciation: A recombination-based approach. New Phytologist 161:107-112.

Navarro A and Barton NH (2003) Chromosomal speciation and molecular divergence - Accelerated evolution in rearranged chromosomes. Science 300:321-324.

Nelson JS (1994) Fishes of the World. Wiley, New York, 523 pp.

Nogusa S (1955) Chromosome studies in Pisces. The chromosomes of Mogrunda obscura (Gobiidae) with evidence of male heterogamety. Cytologia 20:11-18.

Ohno S (1974) Animal Cytogenetics. Chordata 1 - Protochordata, Cyclostomata and Pisces. 4. Gebrüder Borntraeger, Berlin, $92 \mathrm{pp}$.

Park EH and Kang YS (1979) Karyological confirmation of conspicuous ZW sex chromosomes in two species of Pacific anguilloid fishes (Anguilliformes, Teleostomi). Cytogenet Cell Genet 23:33-38.

Pezold F (1984) Evidence for multiple sex chromosomes in the freshwater goby, Gobionellus shufeldti (Pisces, Gobiidae). Copeia 1984:235-238.

Phillips RB and Ihssen PE (1985) Identification of sex chromosomes in lake trout (Salvelinus namaycush). Cytogenet Cell Genet 39:14-18.

Stein JD, Phillips RB and Devlin RH (2001) Identification of sex chromosomes in chinook salmon (Oncorhynnchus tshawytscha). Cytogenet Cell Genet 98:108-110.

Sumner AT (1972) A simple technique for demonstrating centromeric heterochromatin. Exp Cell Res 75:304-306.

Thorgaard GH (1978) Sex chromosomes in the sockeye salmon: A Y-autosome fusion. Can J Genet Cytol 20:349-354.

Uyeno T and Miller RR (1971) Multiple sex chromosomes in a Mexican cyprinodontid fish. Nature 231:452-453.

Vitturi R, Catalano E and Lafargue F (1991) Evidence for heteromorphic sex chromosomes in Zeus faber Pisces Zeiformes nucleolus organizer regions and C-banding pattern. Cytobios 68:37-44.

Associate Editor: Yatiyo Yonenaga-Yassuda 